\title{
Hubungan Pendidikan Formal Dengan Perilaku Pemeriksaan Tuberkulosis Keluarga Kontak Di Kabupaten Pamekasan
}

Ahmadi, Akademi Keperawatan Nazhatut Thullab Sampang

e-mail: ahmadiku373@gmail.com

\section{ABSTRACT}

Tuberculosis is a global problem and until now. In Indonesia tuberculosis became the number one killer among infectious diseases in the other. The disease caused by the Mycobacterium tuberculosis germ is easily transmitted, due out the entry of germs from the body only through the air. The study is quantitative using analitic approach of cross sectional.

Research method with cross sectional approach (cut the latitude) is done at 379 samples using the technique of sampling groups two levels (two-stage cluster sampling).

The results of the statistical test of Pearson Chi Square $p=0000$ value obtained is smaller than $\alpha=0.05$, so that there is a meaningful relationship between inferred levels of education with examination of the behavior of tuberculosis in Pamekasan.

\section{Keywords: educational level, family contacts, conduct inspection of tuberculosis}

\section{PENDAHULUAN}

Tuberkulosis merupakan masalah global dan sampai sekarang belum ada satu pun negara di dunia terbebas dari penyakit ini. Di Indonesia tuberkulosis menjadi pembunuh nomor satu diantara penyakit menular yang lain. Penyakit yang disebabkan oleh kuman Mycobacterium tuberculosis ini mudah sekali menular, karena keluar masuknya kuman dari tubuh hanya melalui udara. Oleh karena itu WHO mengangkat isu tuberkulosis menjadi target utama dalam Sustainable Development Goals (SDGs).

Sampai tahun 2015 Mycobacterium tuberculosis telah menginfeksi sepertiga penduduk dunia, berdasarkan data WHO terdapat sekitar 10,4 juta kasus tuberculosis, sejumlah 5,9 juta (56\%) penderita adalah lakilaki, 4,5 juta (44\%) adalah wanita, 1,0 juta $(10 \%)$ penderita tuberkulosis merupakan menyerang anak-anak. Penderita tuberkulosis dengan HIV menyumbang 1,2 juta (11\%) dari semua kasus tuberkulosis baru. Sulitnya penyembuhan penyakit tuberkulosis pada kasus lama diperparah oleh adanya kasus tuberkulosis baru ditemukan.

Pengendalian penyakit tuberkulosis dilakukan komprehensif mulai dari menemukan kasus, mengobati dan mencegah penderita menularkan penyakit kepada orang disekitarnya. Salah satu indikator pengendalian tuberkulosis di Dunia adalah jika terjadi penurunan kejadian tuberkulosis tiap tahun sampai $(<10 / 100.000)$ penduduk dunia, berkurangnya jumlah kematian akibat tuberkulosis sampai dengan $95 \%$. Pengendalian penyakit tuberculosis dilakukan dengan menerapkan strategi menguatkan sistem kesehatan primer menggunakan model help improve health policies, human resource development, financing, supplies service delivery and information (WHO, 2014)

Tujuan pengobatan tuberkulosis adalah menyembuhkan pasien yang terinfeksi kuman, mencegah kekambuhan penyakit tuberkulosis, penurunan jumlah risiko kematian akibat penyakit, tidak ada resistensi obat, serta memutuskan rantai penularan. Upaya memutus rantai penularan tuberkulosis menjadi prioritas utama. Penularan tuberkulosis akan lebih mudah terjadi pada hunian padat (over crowding), status sosial ekonomi yang kurang (Depkes RI, 2009).

Berdasarkan data Dinas Kesehatan Propinsi Jawa Timur, indikator capaian penemuan kasus baru penderita suspect tuberkulosis Propinsi Jawa Timur berada pada urutan kedua setelah Jawa Barat, namun pada penemuan kasus baru tuberkulosis BTA positif (Case Detection Rate/ CDR), Propinsi Jawa Timur masih menempati urutan ke delapan dari 35 Propinsi di Indonesia. Angka penemuan kasus baru / CDR (case detection rate) penyakit tuberkulosis di Kabupaten Pamekasan yang tercatat pada Dinas Kesehatan Kabupaten Pamekasan untuk seluruh puskesmas pada tahun 2015 rata-rata $39,85 \%$, angka ini tentunya sangat jauh dari target cakupan nasional sebesar $70 \%$.

Skrining tuberkulosis perlu dilakukan untuk mengetahui seseorang tertular penyakit tuberculosis. Anggota keluarga yang tinggal serumah dengan penderita tuberculosis menjadi kekompok rentan tertular karena 
penderita tuberkulosis berisiko menularkan kepada orang lain disekitarnya melalui percikan dahak yang keluar dari penderita (Saptawati, 2012). Kewaspadaan terhadap penularan bisa dilakukan dengan melakukan pemeriksaan sejak dini, meskipun belum ada tanda gejala penyakit tuberculosis, karena jika penderita tidak melakukan pengobatan dengan baik, orang di sekitar penderita juga perlu waspada terhadap penularan.

Pemeriksaan tuberkulosis dilakukan melalui pemeriksaan dahak mikroskopis, kelainan manifestasi klinis dan pemeriksaan radiologi. Pemeriksaan ini berguna untuk diagnosis awal serta pemantauan kemajuan pengobatan tuberkulosis (Depkes RI, 2016). Diagnosis tuberkulosis yang ditegakkan lebih awal bertujuan mencegah terjadinya angka kesakitan atau mempercepat pengobatan sehingga harapan kesembuhan lebih besar dan penularan bisa dicegah. Keterlambatan diagnosis dan pengobatan mempengaruhi jumlah penderita tuberkulosis serta risiko orang lain tertular, satu orang penderita tuberkulosis infeksiosa yang tidak diobati akan menularkan pada 10-15 orang setiap tahun (Agung, 2013).

Sebagian besar masyarakat Madura menganggap penyakit tuberkulosis tidak menular, batuk lama atau dalam istilah di Madura disebut cekle' menurut mereka bisa disembuhkan, dengan cara diambil serta di masukkan ke wadah kemudian di buang atau dikubur. Hal tersebut terjadi secara turun temurun sampai saat ini, sehingga mempengaruhi minat masyarakat untuk memeriksakan diri.

Salah satu penyebab masyarakat tidak melakukan pemerikasaan tuberculosis karena mereka belum memiliki pengetahuan tentang bagaimana penyakit tersebut menular. Hal tersebut terjadi karena tingkat pendidikan sebagian masyarakat yang masih rendah. Tugas keluarga bagi penderita tuberkulosis adalah mengawasi penderita minum obat secara teratur serta mencegah penyakit tuberkulosis tidak menular kepada keluarga lainnya(Heny, 2015).

\section{BAHAN DAN METODE}

Penelitian ini dilaksanakan dengan pendekatan observational, yaitu melakukan pengamatan tanpa memberikan perlakuan terhadap populasi tetapi menganalisis pengaruh variabel yang sudah ada.Pengamatan dilakukan secara terencana antara lain melihat, mendengar, dan mencatat sejumlah kegiatan tertentu yang ada hubungan dengan penelitian yang sedang dilakukan (Notoatmodjo, S. (2015).

Penelitian ini bersifat analitic kuantitatif yaitu memanfaatkan analisis cross sectional. Metode ini menggunakan model pengamatan sekali waktu antara pengukuran dengan pengamatan (Hidayat, A. (2008). Lokasi penelitian ini dilakukan di Kabupaten Pamekasan, jadwal pengambilan data penelitian dilakukan mulai Desember 2016 sampai bulan Agustus 2017. Penetapan tempat penelitian di Kabupaten Pamekasan didasarkan pada fenomena angka case detection rate semua puskesmas Kabupaten Pamekasan.

Populasi dalam penelitian ini adalah keluarga kontak erat penderita tuberkulosis paru (care giver) di Kabupaten Pamekasan dengan jumlah 881 orang. Berdasarkan hasil rumus hitung besar sampel didapatkan bahwa paling sedikit sampel yang dibutuhkan untuk penelitian ini berjumlah 379 sampel. Sementara Teknik pengambilan sampel yang digunakan adalah sampling kelompok dua tingkat (two stage cluster sampling). Pengumpulan data diambil secara langsung kepada subjek menggunakan lembar kuisioner penelitian berupa kuesioner pada seluruh responden jika memenuhi kriteria inklusi. Setelah mengumpulkan data menggunakan kuesioner penelitian, data tersebut selanjutnya diolah menjadi data kuantitatif, penentuan skor tiap jawaban dari responden dibuat berdasarkan ketetapan yang dibuat oleh peneliti (Sugiyono. (2008).

\section{HASIL}

Analisis Crosstab dilaksanakan untuk mengetahui hubungan antara variabel dependen dan independen. Pada analisis penelitian ini variabel tingkat pendidikan formal dihubungkan dengan variabel perilaku pemeriksaan tuberculosis

Tabel 1. Distribusi frekuensi responden berdasar pada karakteristik umur tahun 2017

\begin{tabular}{ccc}
\hline Umur & Jumlah & Persentase (\%) \\
\hline 20-29 tahun & 130 & 34.3 \\
30-39 tahun & 159 & 42.0 \\
40 -49 tahun & 78 & 20.6 \\
>50 tahun & 12 & 3.2 \\
\hline Total & 379 & 100.0 \\
\hline
\end{tabular}

Dari tabel 1.terlihat bahwa sebagian besar responden terdiri dari kelompok umur 3039 tahun sebanyak 159 (42.0\%), proporsi tersebut menandakan jika sebagian besar responden berada pada kelompok umur produktif. 
Tabel 2. Distribusi frekuensi responden jerdasarkan tingkat pendidikan tahun 2017

\begin{tabular}{ccc}
\hline Pendidikan & Jumlah & Persentase \\
\hline Tidak Sekolah & 15 & 4.0 \\
SD & 135 & 35.6 \\
SMP & 146 & 38.5 \\
SMA Sederajat & 56 & 14.8 \\
PT & 27 & 7.1 \\
\hline Total & 379 & 100.0 \\
\hline
\end{tabular}

Dari tabel 2 diketahui karakteristik responden berdasarkan tingkat pendidikan responden sebagian kecil tidak sekolah sebanyak $15 \quad(4.0 \%)$ responden. Tingkat pendidikan mempengaruhi perilaku kesehatan, karena tingkat pendidikan berkaitan erat dengan kemampuan individu menyerap informasi.

Tabel 3. Analisis hubungan Tingkat Pendidikan dengan pemeriksaan tuberkulosis di Kabupaten Pamekasan tahun 2017

\begin{tabular}{cccccccc}
\hline \multirow{2}{*}{ Pendidikan } & \multicolumn{3}{c}{ Pemeriksaan tuberkulosis } & \multicolumn{3}{c}{ Total } & \multirow{2}{*}{$\boldsymbol{P}$ value } \\
\cline { 2 - 6 } & Tidak periksa & $\%$ & Periksa & $\%$ & $\mathbf{N}$ & $\%$ & \\
\hline TS & 14 & 3.7 & 1 & 0.3 & 15 & 4.0 & \\
SD & 87 & 23 & 48 & 12.7 & 135 & 35.6 & \\
SMP & 91 & 24 & 55 & 14.5 & 146 & 38.5 & 0.000 \\
SMA & 31 & 8.2 & 25 & 6.6 & 56 & 14.8 & \\
PT & 4 & 1.1 & 23 & 6.1 & 27 & 7.1 & \\
\hline Total & 227 & 59.9 & 152 & 40.1 & 379 & 100 & \\
\hline
\end{tabular}

Tabel 3 menjabarkan bahwa

berdasarkan tingkat pendidikan responden yang terlibat dalam penelitian adalah tingkat SMP sebanyak 146 (38.5) dari total responden, dari jumlah tersebut hanya sebesar 55 (14.5\%) responden melakukan pemeriksaan tuberkulosis. Hasil uji menggunakan Pearson Chi Square didapatkan hasil $p=0.000$ kurang dari dari $\alpha=0.05$, kesimpulan yang bisa ditarik ada hubungan bermakna tingkat pendidikan dengan perilaku pemeriksaan tuberkulosis di Kabupaten Pamekasan.

\section{PEMBAHASAN}

Hasil analisis deskriptif menunjukkan bahwa hampir separuhnya pendidikan formal responden penelitian adalah Sekolah Menengah Pertama (SMP) sederajat. Menurut Palupi (2011), tingkat pendidikan dapat mempengaruhi pengetahuan seseorang. Tingkat pendidikan seseorang berpengaruh pada pola pikir dan daya nalar dalam menghadapi masalah. Tingkat pengetahuan seseorang dipengaruhi oleh faktor internal meliputi intelegensia, minat dan kondisi fisik, serta faktor eksternal yang dipengaruhi faktor keluarga, masyarakat, sarana dan prasarana kesehatan, dan faktor pendekatan belajar meliputi strategi dalam belajar serta metodeyang digunakan ketika proses belajar (Notoatmodjo, 2012).

Analisis bivariat menunjukkan bahwa tingkat pendidikan responden pada Perguruan Tinggi mempengaruhi perilaku pemeriksaan tuberkulosis sebesar $78.6 \%$, dibanding tingkat pendidikan SD sebesar $34.4 \%$. Hal tersebut diperkuat dengan hasil uji statistik yang menunjukkan adanya signifikansi antara tingkat pemeriksaan penyakit ke pelayanan kesehatan.

Konteks Pendidikan masyarakat madura bisa di lihat dari peribahasa orang madura "Buppa, Babbu', Guruh, Ratoh" dari peribahasa tersebut tersirat makna mendalam sebagai berikut "Buppa, Babbu' Bapak dan Ibu sebagai figure panutan dalam masyarakat yang tinggal di pulau madura. Dilihat dari dari sisi sosial, figur lain yang juga menjadi panutan serta paling dihormati di Madura yaitu "Guruh tolang" atau Kiai terutama guru ngaji yang pertama kali mengajarkan cara mengaji. Sosok Kiai bagi masyarakat di pulau Madura adalah pendidik yang mengajarkan pengetahuan akidah serta ahlakul karimah atau perilaku baik. Petuah para Kiai merupakan tuntunan kehidupan serta pedoman untuk menjalankan hidupan didunia serta ketika diakhirat. Sosok terakhir yang menjadi panutan Masyarakat Madura adalah "Ratoh" Pemerintah, petugas kesehatan ataupun pejabat negara.

Mayoritas masyarakat menganggap sekolah formal sebagai alternatif menuntut ilmu setelah pondok pesantren, oleh karena itu meskipun tingkat pendidikan formal sebagian masyarakat masih rendah, namun secara informal mereka sudah mengenyam pendidikan lebih tinggi dari SMP, hal itu mempengaruhi partisipasi masyarakat dalam penanggulangan penyakit tuberkulosis, karena mereka mampu menyerap informasi yang mereka dapatkan dari berbagai sumber. 


\section{KESIMPULAN}

Ada pengaruh antara pendidikan formal dengan pelaksanaan pemeriksaan tuberkulosis keluarga kontak di Kabupaten Pamekasan

\section{DAFTAR RUJUKAN}

Agung, A. A. G., Sawitri, A. A. S., \& Wirawan, D. N. (2013). Low proportion of contact among people attending early detection for pulmonary tuberculosis in Denpasar Selatan I Community Health Center Year 2012. Journal Health and Preventive Medicine Archive, 1(1), 55-62.

Depkes RI. (2009). Buku Saku Program Penaggulangan TB. Departemen Kesehatan RI.

Depkes RI. (2016). InfoDatin. In Tuberkulosis temukan obati sampai sembuh (pp. 2-10). Jakarta.

Heny, H. (2015). The Influence of Empowering TB (Tuberculosis) Patients 'Family on Capability of Implementing The Family Health Task in Martapura and Astambul Public Health Center Areas in Banjar District. Jurnal Buletin Penelitian Sistem Kesehatan, 18(4), 407-419.

Hidayat, A.A,. (2008). Metode Penelitian Keperawatan dan Teknik Analisis Data. Ed 2. Jakarta: EGC, hal. 60-61.

Kristiono, R. S., \& Wardani, Y. (2013). Faktorfaktor yang berhubungan dengan pola pencarian pengobatan ke pelayanan kesehatan alternatif pasien suspek tuberculosis di komunitas. Jurnal Kesehatan Masyarakat (Journal of Public Health), 7(2), 55-112.

Notoatmodjo, S. (2015). Metodologi Penelitian Kesehatan. Jakarta: Rineka Cipta.

Notoatmodjo, S. (2012). Promosi Kesehatan dan Perilaku Kesehatan. Jakarta: Rineka Cipta, hal. 131-134.

Palupi, D. L. M. (2011). Pengaruh Pendidikan Kesehatan Terhadap Perubahan Pengetahuan,Sikap dan Perilaku Penderita Tuberculosis yang Berobat di Wilayah Kerja Puskesmas Surakarta. Jurnal Program Studi Pendidikan Kedokteran Keluarga, Program Pasca Sarjana, Universitas Sebelas Maret Surakarta, 1(2), 1-15.

Saptawati, L., Mardiastuti, Karuniawati, A., \& Rumende, C. M. (2012). Evaluasi Metode FastPlaqueTB Untuk Mendeteksi Mycobacterium Tuberculosis Pada Sputum Di Beberapa Unit Pelayanan Kesehatan Di Jakarta-Indonesia. Jurnal Tuberkulosis Indonesia, 8(2), 1-6.

Sugiyono. (2008). Metode Penelitian Kuantitatif Kualitatif dan R\&D. Bandung: Alfabeta

WHO. (2014). Global Tuberculosis Report 2014. WHO Report, 4, 1-171. 